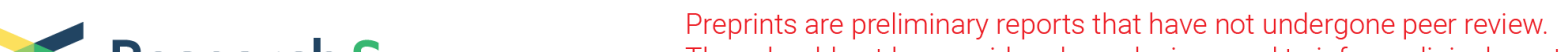 $\begin{array}{ll}\text { Research Square } & \text { They should not be considered conclusive, used to inform clinical practice, } \\ \text { or referenced by the media as validated information. }\end{array}$
}

\section{Orange Layered Patinas on Limestone Surface in the Batalha Monastery (Portugal): Characterization and Decay Patterns}

\section{YUFAN DING ( $\nabla$ yding@uevora.pt)}

Universidade de Évora https://orcid.org/0000-0002-1983-6057

\section{Pedro Redol}

Patrimonio Cultural

\section{Emma Angelini}

Politecnico di Torino

Jose Mirao

Universidade de Évora: Universidade de Evora

\section{Nick Schiavon}

Universidade de Évora: Universidade de Evora

\section{Research Article}

Keywords: limestone balustrade, Batalha Monastery, Ca-oxalate patinas imbedding soil dust airborne particles, Mediterranean region

Posted Date: April 5th, 2021

DOl: https://doi.org/10.21203/rs.3.rs-246293/v1

License: (1) This work is licensed under a Creative Commons Attribution 4.0 International License.

Read Full License

Version of Record: A version of this preprint was published at Environmental Science and Pollution Research on July 29th, 2021. See the published version at https://doi.org/10.1007/s11356-021-15490-1. 


\section{Abstract}

Samples of orange patinas found on a limestone balustrade and an ornament of the Batalha Monastery have been investigated by X-ray micro-diffractometry ( $\mu$-XRD) and Low-Vacuum Scanning Electron Microscopy coupled with Energy Dispersive Spectrometry (LV-SEM + EDS). Aim of the study was to determine the composition of the layered patinas, assess whether they were been intentionally applied or naturally formed, and study their degradation patterns. Preliminary results revealed that the orange patinas on the balustrade and the ornament showed different compositions and appearance, suggesting distinct formation pathways. Orange layers on the ornament which suffers salt decay and delamination nowadays, mainly consisted of gypsum with hematite as a minor component, implying the possibility of an intentional application of a mixture of ochre and lime as tint plaster. Orange patinas on the balustrade show the presence of Ca-oxalates, abundant weddellite and minor whewellite, with minor hematite suggesting the yellowish/orange color to be due to Ca-oxalate patinas imbedding soil dust airborne particles. Such patina was possibly formed naturally either by the chemical attack due to atmospheric air pollutants from traffic exhausts emissions or by bacterial activity. No delamination was observed, abrasion is the major decay phenomenon on the balustrade sample. A comparison was made between this patina and the so called "scialbatura", a surface yellowish coating often found by conservators on limestone and marble in ancient monuments in the Mediterranean region.

\section{Introduction}

The famous Batalha Monastery located in Central Portugal was built and restored using Jurassic oolitic limestones extracted from several quarries in the region surrounding the monument (Aires-Barros 2001; Ding et al. 2019). Although originally white in color, nowadays the monastery building limestone is now extensively covered with orange patinas which can be seen on the surface of facades, ornaments, columns and walls (Fig. 1). Few studies on this subject can be found in the literature. Rattazzi and coworkers examined two statues kept in the Monastery museum storage: the external orange layers were found to show a rather homogeneous texture with traces of gypsum and clay minerals; FTIR analysis showed bands of Al-silicates and iron oxides, interpreted as Earth of Sienna natural and Red Ochre pigments (Rattazzi et al, 1996). Aires-Barros et al. investigated the original $15^{\text {th }}$ century Saint Matthew statue and the external walls of the main façade. The statue showed the presence of calcite with minor nitrate, silicate and organic products like benzoic acid, while on the external walls the orange patinas were found to be predominantly composed by calcium oxalates such as whewellite $\left(\mathrm{CaC}_{2} \mathrm{O}_{4} \cdot \mathrm{H}_{2} \mathrm{O}\right)$ with minor weddellite $\left(\mathrm{CaC}_{2} \mathrm{O}_{4} \cdot 2 \mathrm{H}_{2} \mathrm{O}\right)$, together with hydroxyapatite $\left(\mathrm{Ca}_{5}\left(\mathrm{PO}_{4}\right)_{3}(\mathrm{OH})\right)$, halloysite and nitrates (AiresBarros et al, 2001).

These results suggested these patinas to represent what conservators called "scialbatura" i.e.: a superficial film present as a surface coating on calcareous Greek and Roman monuments in the urban areas, colored variously yellow, brown, pink or red, often associated with pitting phenomena (Lazzarini and Salvadori 1989). In the late 1980's, researchers demonstrated that its principal components were Ca-oxalates mainly weddellite and whewellite, iron oxides (ochres), gypsum calcite from the underlying marble substrate, 
quartz and feldspars as windborne soil dust, and gypsum related to the reaction between atmospheric $\mathrm{SO}_{2}$ derived from fossil fuel, oil and coal burning processes (Del Monte and Sabbioni 1987). In fact, the origin of oxalates present on limestone surfaces in urban environments has been the subject of intense debate for decades and regarded as being due to different chemical and biogenic processes such as: a) oxalate mineral precipitation associated with chemical attack on calcite-rich substrates of oxalic acid due to metabolic activity of encrusting epilithic lichens (Del Monte et al. 1987; Rosado et al, 2016); b) non-biomediated chemical reactions between the calcareous stone substrate and a number of natural and manmade organic pollutants found in the urban atmosphere from volcanic activity and industrial production activities (Camuffo 1993), and/or vehicle exhaust emissions (Kawamura and Kaplan 1987); and c) organic compounds used in past decorative or protective treatments and responsible for oxalate formation, such as calcium caseinate, egg, milk, etc. (Lazzalini and Salvatori 1989; Frazini et al. 1984), "Scialbatura" patinas has been also considered to represent intentionally added "sacrificial" coating for the monuments eventually leading, though, to further stone decay (Demitry 1988). In the following up studies, Fassina (1995) considered lime as being the main component of the traditional "scialbatura", with, in addition, titanium oxide detected in the yellow-pink layer. The yellow color was interpreted as related to the presence of fluorite probably formed during the superficial consolidation using fluorosilicate treatments or alternatively to acid cleaning interventions.

Nearly 15 years have passed since the last research carried out on this topic. In this research, two fragments from the Batalha Monastery - an ornament and a balustrade section have been investigated. Aim of this study was to determine the composition of the orange layers on their surface, make a comparison between each other and with previous research results. Another aim was to assess the possible interactions between the oolitic limestone substrate, the orange surface patinas and the urban environment surrounding the Monastery.

\section{Methods And Materials}

By special permission of the Direção-Geral do Patrimonio Cultural and the Mosteiro da Batalha authorities, 2 fragments were sampled from the monastery to HERCULES Laboratory (University of Evora) to carry out the characterization: one is an ornament from the west portal of the church - "S-116" (Fig. 2) from 15 th century, the other is an ornament from a window tracery in the Royal Cloister (Fig. 3). Complying with the principle of non-destructive detection, the following analytical methods were used.

\section{X-ray micro-diffractometry ( $\mu$-XRD)}

Multiple points on the orange layer and the substrate of the samples (Fig. 2 and Fig. 3) were characterized by $\mu$-X-ray diffraction using a commercial Bruker AXS D8 Discovery diffractometer with Cu Ka radiation, Lynxeye detector, interval $3-70^{\circ} 2 \mu$, and step of 0.028 /s (Valadas et al. 2011). DIFFRAC.SUITE EVA and Highscore Plus software were used to identify the mineralogical composition and do a quantification by the RIR method (Hubbard et al. 1988). 
Variable-pressure scanning electron microscopy coupled with energy dispersive spectrometry (VP-SEM + EDS).

Scanning electron microscopy coupled with energy dispersive X-ray spectrometry were carried out using a Hitachi S3700N (Tokyo, Japan) SEM coupled to a Bruker (Karlsruhe, Germany) XFlash 5010 SDD Detector system (Veiga et al, 2014). The samples were characterized at a chamber pressure of $40 \mathrm{~Pa}$, without any sample preparation, with an accelerating voltage of $20 \mathrm{kV}$, using a working distance $10 \mathrm{~mm}$ and a BSEM detector.

\section{Results And Discussion}

\section{Ornament "S-116" from Batalha Monastery}

$\mu$-X-ray diffraction patterns were acquired on six points of the ornament "S-116" and a peeled off fragment, as shown in Fig. 2. Point 1, 2, 4 and 6 were acquired on the orange surface patinas whereas Points 3 and 5 were acquired on the substrate where the orange surface had already peeled off with the limestone substrate showing extensive decay. The XRD pattern and peaks are presented in Fig. 4, and a semi-quantitative evaluation is given in Table 1.

In both samples, the stone substrate is an oolitic limestone consisting mainly of calcite and quartz (Ding et al, 2019): accordingly, peaks of both minerals are seen at all points. A considerable amount of gypsum can be detected at point 1, 2, 4, 6 and in the detached fragment, in areas corresponding to the orange surface, while at point 3 and 5 where the coating is completely removed, gypsum is absent. Halite was present in all analyzed spots, with its content being significantly higher at point 3 and 5 , indicating that halite is concentrated on the substrate surface under the orange layer. Feldspar peaks (Al-K-silica) are present particularly at point 1, confirming the presence of soil dust deposition in this area. A minor amount of hematite was detected in all orange patinas suggesting the presence of red ochre pigment.

The sporadic presence of ettringite peaks in XRD results is somewhat intriguing. The presence of ettringite could be due to the cementitious materials exposed to sulphate: calcium aluminate hydrates and calcium silicate hydrates mixed with lime, can react with water and gypsum or other sulphate salts, to produce ettringite $\left[\mathrm{Ca}_{6} \mathrm{Al}_{2}\left(\mathrm{SO}_{4}\right)_{3}(\mathrm{OH})_{12} \cdot 26 \mathrm{H}_{2} \mathrm{O}\right]$ and thaumasite $\left[\mathrm{Ca}_{3} \mathrm{Si}(\mathrm{OH})_{6}\left(\mathrm{CO}_{3}\right)\left(\mathrm{SO}_{4}\right){ }_{12} \mathrm{H}_{2} \mathrm{O}\right]$ Collepardi (1999). The application of cement-based mortar in the Batalha monastery during past restoration interventions (Soares 2001) could be the reason for the presence of ettringite on the ornament surface.

The peeled-off fragment was observed under the VP-SEM+EDS: results are shown in Fig. $\mathbf{5}$. There is a correlation between the distribution of sodium and chloride, demonstrating the presence of halite $(\mathrm{NaCl})$ grains. Potassium (K), aluminum (Al) and silicon ( $\mathrm{Si}$ ) peaks imply the presence of quartz, feldspar and clays minerals probably as soil dust. The peak of calcium (Ca) is weak where the $\mathrm{NaCl}$ and feldspar / soil dust / clay grain are present, which means halite and aluminosilicates were formed subsequently on the top of the limestone substrate. This could also be seen from the SEM picture, the halite (up left) and 
feldspar (down central) show a well-formed crystalline habit with relatively large dimension grains (>50 $\mu \mathrm{m})$, in contrast with the poorly crystallized gypsum grains.

The distribution of iron $(\mathrm{Fe})$ is homogenous over the whole area, supporting the interpretation of a pigment surface application. On the other hand, hematite is also present as accessory mineral grains in the original limestone. The presence of sulfur $(\mathrm{S})$ is mainly due to gypsum $\left(\mathrm{CaSO}_{4} \cdot 2 \mathrm{H}_{2} \mathrm{O}\right)$; its distribution is basically uniform and some collective grains can be seen. By overlapping the distribution of Fe and S (Fig. 6) it shows the hematite was likely to be mixed and applied together with gypsum on the uppermost layer. This hypothesis can be supported by the recorded use of red and yellow ochre: in ancient Macedonian paintings, one of the major means of using ochre is to mix them with lime to produce tint plasters then apply on the monuments (Perdikatsis and Brecoulaki 2008). Therefore, the color on the ornament "S-116" surface could be by reason of the same procedure. It is noteworthy the presence of phosphorous $(P)$, which was also detected by Lazzalini and Salvatori (1989) on the "scialbatura" of Cathedral and church of S.Zeno, Verona, they inferred that the presence of phosphorus suggests an artificial protective coating made from calcium caseinate.

\section{Balustrade from Batalha Monastery Royal Cloister}

The balustrade sample (Fig. 5) was analyzed only by XRD as a bulk to prevent causing any damage. Fig. 6 shows the XRD pattern, and in Table 2 the main minerals are listed together with their semi-quantitative evaluation. It is shown that, at point 1 , where an orange surface is still visible, there is a high content of calcium oxalate including weddellite and whewellite, together with feldspar and hematite. Gypsum was detected where the orange surface is worn-out and the white substrate appears, the main composition is calcite, and the contents of gypsum and calcium oxalate show a decrease, also hematite was not detected. Point 3 has a different appearance other than point 1, the surface shows a dark orange color and the texture is loose and powdery, the XRD result revealed calcite, some weddellite, feldspar, and minor hematite. Halite was present at point 3 and absent at points 1 and 2.

Calcium oxalate is itself colorless but when organic compounds, mainly derived from the metabolic activity of lichens, fungi and bacteria (from oxalic acid which reacts with calcite to form a thin calcium oxalate film) and other mineral grains (such as quartz, feldspar) are present, the patina may acquire a yellowish-brown hue (lon et al. 2017). Thus, the color on this balustrade could possibly originate from calcium oxalate mixed with other mineral grains such as soil dust. The stone surface oxalates were generally considered to be the result of lichen excreted oxalic acid that reacts with calcium in the substrate (Del Monte et al. 1987), however, a few recent studies reported that various bacteria can produce oxalic acid even without lichen microbiomes, for instance, Pseudomonas fluorescens, Burkholderia, Bacillus and C. jiangningensis JN53, etc. (Palmieri et al. 2019; Hess et al. 2008; Cheng et al. 2017). In fact, Bacillus (phylum Firmicutes) and Burkholderia (phylum Beta-Proteobacteria) were found in the Batalha Monastery bio-deteriorated stone and the atmospheric environment in the previous study by the authors (Ding et al. 2021). Thus, although no lichen crust was present on this balustrade sample, the possibility of bacteria producing oxalic acid and causing mineral weathering cannot be excluded. 
Calcium oxalates may also be deriving from vehicular exhaust emissions (Kawamura and Kaplan 1987) suggested that incomplete combustion of aromatic hydrocarbons (such as benzene, toluene, naphthalene) in the car engines could generate diacids including oxalic acid, cis-unsaturated acids and aromatic acids. Due to the polar nature of these dicarboxylic acids, they preferentially associate with moisture and would react with calcareous stone and form calcium oxalates. As a matter of fact, the Portuguese national highway IC2 run through Batalha only 50 meters west of the monastery, so atmospheric vehicular pollution could not be ruled out as a cause for the development of oxalate patinas on the limestone surface. And the benzoic acid found by Aires-Barros et al (2001) on the external walls of this monument, makes this hypothesis more plausible.

\section{Comparison between the two samples}

Though both named "orange patinas", there are significant differences between the two samples investigated. Table 3 lists these differences of these two samples with respect to composition, appearance and decay patterns. For the ornament "S-116", the orange layer follows the external shaping, for example, the ridging stripes spreading out from the center, which does not exist on the substrate. For the Royal Cloister balustrade, the orange patina is closely adherent to the limestone substrate instead of a visible separate layering present on "S-116". And there is an abundant weddellite on the balustrade surface, which was not found on the sample "S-116".

The decay pattern of these orange layers on the two samples are also distinct. On the ornament "S-116", the surface layer is flaking, on the white substrate under the peeled-off lamination, higher content of halite was detected. This indicates a typical salt decay process: salt solution evaporated and crystallized at the interface between the coating and the substrate, leading to detachment eventually (Duffy et al. 1996). In this case, the salt responsible for decay is mainly halite $(\mathrm{NaCl})$, its precipitation leading to salt decay in the monastery may probably derive from ground-moisture capillary rise. Considering the Royal Cloister balustrade, the patina is lost preferentially at the ridges and bulges but is more preserved in flat areas where marks of scratches can also be seen. Three possible explanations can be suggested: a) the evaporation rate of salt solutions is higher at the geometrically protruded parts due to a larger specific surface area, resulting in higher crystallization pressure inside the stone pores and more severe decay (Rodriguez et al. 1999); b) protruded areas endure more mechanical abrasion from rain, wind, sands, and human activities, thus accelerating the decay processes; or c) the orange patina was originally formed irregularly on the substrate.

Combing the results obtained, preliminary sketch (Fig. 8) was made to elucidate the different characteristic of the two samples investigated.

\section{Comparison with the previous research}

Through the above-mentioned results and analysis, it can be concluded that the orange layer on the Royal Cloister balustrade is similar to the findings by Aires-Barros et al (2001). Such patina is compatible with a "scialbatura" nature for its composition, texture and color, as described by Lazzalini and Salvatori (1989). 
No titanium oxide and fluorite presence as reported in previous research (Fassina 1995). The existing results are in favor of the conclusion that the presence of calcium oxalates on this monastery could be linked to either vehicular exhaust emissions (Kawamura and Kaplan 1987) or by bacterial activity (Palmieri et al. 2019), but not to oxalic production by lichenous colonization (Del Monte and Sabbioni 1987).

The orange coating on the ornament "S-116" sample matches the description of that on the original apostle statues from the church doorway (Rattazzi et al. 1996). Considering the ornament "S-116" and the apostle statues were both crafted in the 15th century, it is feasible that the same coating procedure was used, despite they were located in different sites of the Batalha Monastery. Although it is commonly believed that in this type of surface layers, the gypsum occurring on calcareous stones is a reaction product of calcareous or silicate stones in a $\mathrm{SO}_{2}$ polluted urban atmosphere (Schiavon 2007), the possibility of artificial gypsum coating cannot be completely excluded (Sánchez 2009). In fact, the homogeneity of the layers and its mixing with hematite, may support the conclusion of the intentional application of a pigmented plaster.

\section{Conclusion}

In this research, a chemical / mineralogical characterization was carried out on orange surface patinas found in two different limestone artifacts from Batalha Monastery in Portugal. The homogenous and decorative layer on ornament "S-116" is mainly composed of gypsum and hematite with traces of K-Al-Si silicates possibly from soil dust and mortar joints in the monument. It is highly likely to be applied intentionally, using the same craft procedure as the apostle statues of the monastery. Its delamination is a typical phenomenon of salt decay, for high concentration of halite was found on the substrate under the exfoliated surface.

The colored surface of the Royal Cloister balustrade contains abundant calcium oxalate including weddellite and whewellite, gypsum was also detected. The surface color is not homogeneous on the balustrade piece where erosive episodes lead to surface loss. Based on the above results, this surface layer is compatible with the description of "scialbatura", and it shows evidence of substrate stone reacting with the environment. This patina was likely generated due to the air pollution and the bacterial metabolism.

\section{Declarations}

Ethics approval and consent to participate Not applicable for this study.

Consent to publish All authors consent to this publication.

\section{Availability of data and materials}

Competing interests The authors declare that they have no competing interests. 
Funding This research has received funding from the European Union's Horizon 2020 research and innovation programme under the Marie Skłodowska-Curie grant agreement No 766311.

Authors' contributions Conceptualization: Nicola Schiavon, José Mirão, Yufan Ding; Methodology: Nicola Schiavon, José Mirão, Yufan Ding; Formal analysis and investigation: Yufan Ding, Nicola Schiavon; Writing - original draft preparation: Yufan Ding; Writing - review and editing: Pedro Redol, Nicola Schiavon, Yufan Ding; Funding acquisition: Nicola Schiavon, Yufan Ding; Resources: Pedro Redol; Supervision: Nicola Schiavon, Emma Angellini.

Acknowledgements Samples collection in this research was by special permission of the Direção-Geral do Patrimonio Cultural and the Mosteiro da Batalha authorities. The research presented in this paper was carried out mainly using data collected at Universidade de Évora, Politecnico di Torino and Direcao-Geral do Patrimonio Cultural, as part of H2020-MSCA-ITN-2017, ED-ARCHMAT (ESR1).

\section{References}

1. Aires-Barros, L., Basto, M. J., Dionísio, A., \& Charola, A. E. (2001). Orange coloured surface deposits on stones from the Monastery of Batalha (Portugal) and from nearby historic quarries: characteristics and origins. International Journal for Restoration of Buildings and Monuments, 7(5), 491-506. https://doi.org/10.1515/rbm-2001-5594

2. Aires-Barros, L. (2001). As rochas dos monumentos portugueses: tipologias e patologias. volume II, 453-471. Instituto Português do Património Arquitectónico. ISBN-13: 9789728087814.

3. Camuffo, D. (1993). Reconstructing the climate and the air pollution of Rome during the life of the Trajan Column. Science of the total environment, 128(2-3), 205-226.

4. Cheng, C., Wang, Q., He, L., \& Sheng, X. (2017). Change in mineral weathering behaviors of a bacterium Chitinophaga jiangningensis JN53 under different nutrition conditions. Journal of basic microbiology, 57(4), 293-301. https://doi.org/10.1002/jobm.201600652

5. Collepardi, M. (1999). Thaumasite formation and deterioration in historic buildings. Cement and Concrete Composites, 21(2), 147-154. https://doi.org/10.1016/S0958-9465(98)00044-4

6. Del Monte, M., \& Sabbioni, C. (1987). A study of the patina called 'scialbatura'on imperial Roman marbles. Studies in Conservation, 32(3), 114-121. https://doi.org/10.1179/sic.1987.32.3.114

7. Del Monte, M., Sabbioni, C., \& Zappia, G. (1987). The origin of calcium oxalates on historical buildings, monuments and natural outcrops. Science of the Total Environment, 67(1), 17-39.

8. Demitry, L. (1988). The conservation of the Stadium of Domizian in Rome. In VIth International Congress on Deterioration and Conservation of Stone, Torun, 12-14 September 1988. Proceedings (pp. 748-756).

9. Ding Y., Mirao J., Redol P., Dias L., Moita P., Angellini E., Grassini S., Schiavon N. (2019) A combined petrographic and geochemical metrological approach to assess the provenance of the building limestone used in the Batalha Monastery (Portugal). BATTISTI, V., \& GALLO, V. (2019). METROLOGY FOR ARCHAEOLOGY AND CULTURAL HERITAGE, 338. 
10. Ding, Y., Salvador, C. S. C., Caldeira, A. T., Angelini, E., \& Schiavon, N. (2021). Biodegradation and Microbial Contamination of Limestone Surfaces: An Experimental Study from Batalha Monastery, Portugal. Corrosion and Materials Degradation, 2(1), 31-45. https://doi.org/10.3390/cmd2010002

11. Duffy, A. P., \& Perry, S. H. (1996). The mechanisms and causes of Portland Limestone decay-A Case Study. In 8th International Congress on Deterioration and Conservation of stone (Vol. 1, pp. 135-145).

12. Fassina, V. (1995). New findings on past treatments carried out on stone and marble monuments' surfaces. Science of the total environment, 167(1-3), 185-203. https://doi.org/10.1016/00489697(95)04580-T

13. Franzini, M., Gratziu, C., \& Wicks, E. (1984). Patine ad ossalato di calcio su monumenti marmorei. Societa Italiana di Mineralogia e Petrologia, 39(1), 59-70.

14. Hess, D., Coker, D. J., Loutsch, J. M., \& Russ, J. (2008). Production of oxalates in vitro by microbes isolated from rock surfaces with prehistoric paints in the lower Pecos region, Texas. Geoarchaeology: An International Journal, 23(1), 3-11. https://doi.org/10.1002/gea.20208

15. Hubbard, C. R., \& Snyder, R. L. (1988). RIR-measurement and use in quantitative XRD. Powder Diffraction, 3(2), 74-77. https://doi.org/10.1017/S0885715600013257

16. Ion, R. M., Teodorescu, S., Ştirbescu, R. M., Bucurică, I. A., Dulamă, I. D., \& Ion, M. L. (2017). Calcium oxalate on limestone surface of heritage buildings. In Key Engineering Materials (Vol. 750, pp. 129134). Trans Tech Publications Ltd. https://doi.org/10.4028/www.scientific.net/KEM.750.129

17. Kawamura, K., \& Kaplan, I. R. (1987). Motor exhaust emissions as a primary source for dicarboxylic acids in Los Angeles ambient air. Environmental science \& technology, 21(1), 105-110.

18. Lazzarini, L., \& Salvadori, O. (1989). A reassessment of the formation of the patina called scialbatura. Studies in conservation, 34(1), 20-26. https://doi.org/10.1179/sic.1989.34.1.20

19. Palmieri, F., Estoppey, A., House, G. L., Lohberger, A., Bindschedler, S., Chain, P. S., \& Junier, P. (2019). Oxalic acid, a molecule at the crossroads of bacterial-fungal interactions. Advances in applied microbiology, 106, 49-77.

20. Perdikatsis, V., \& Brecoulaki, H. (2008). The use of red and yellow ochres as painting materials in Ancient Macedonia. BAR International Series, 1746, 559.

21. Rattazzi, A., Camaiti, M., \& Salvioni, D. (1996). The statues of the apostles from the main doorway of the church of the Monastery of Batalha (Portugal): analysis of degradation forms in relation to ancient treatments. In Proceedings of the 8th International Congress on Deterioration and Conservation of Stone, J. Riederer, Editor, Möller Druck und Verlag, Berlin (pp. 101-108).

22. Rodriguez-Navarro, C., \& Doehne, E. (1999). Salt weathering: influence of evaporation rate, supersaturation and crystallization pattern. Earth Surface Processes and Landforms: The Journal of the British Geomorphological Research Group, 24(3), 191-209. https://doi.org/10.1002/(SICl)10969837(199903)24:3<191::AID-ESP942>3.0.CO;2-G

23. Rosado, T., Silva, M., Galvão, A., Mirao. J., Candeias, A. \& Caldeira, A.T.C. A first insight on the biodegradation of limestone: the case of the World Heritage Convent of Christ. Appl. Phys. A122, 1012 (2016). https://doi.org/10.1007/s00339-016-0525-6 
24. Sánchez, J. S., Alves, C. A. S., Romaní, J. V., \& Mosquera, D. F. (2009). Origin of gypsum-rich coatings on historic buildings. Water, air, and soil pollution, 204(1-4), 53. https://doi.org/10.1007/s11270-0090025-9

25. Schiavon, N. (2007) Kaolinization of Granite in an Urban Environment. Environmental Geology, 52(2), 399-407. https://doi.org/10.1007/s00254-006-0473-0

26. Soares, C. M. (2001). O restauro do mosteiro da batalha: pedreiras históricas, estaleiro de obras e mestres canteiros. Magno Ed. ISBN 9728345283.

27. Valadas, S., Candeias, A., Mirão, J., Tavares, D., Coroado, J., Simon, R., ... \& Carvalho, M. L. (2011). Study of Mural Paintings Using In Situ XRF, Confocal Synchrotron- $\mu-X R F, \mu-X R D$, Optical Microscopy, and SEM-EDS-The Case of the Frescoes from Misericordia Church of Odemira. Microscopy and Microanalysis, 17(5), 702-709. https://doi.org/10.1017/S1431927611000195

28. Veiga, A., Mirão, J., Candeias, A. J., Simões Rodrigues, P., Martins Teixeira, D., Muralha, V. S., \& Ginja Teixeira, J. (2014). Pigment analysis of Portuguese portrait miniatures of 17 th and 18 th centuries by Raman Microscopy and SEM-EDS. Journal of Raman Spectroscopy, 45(10), 947-957. https://doi.org/10.1002/jrs.4570

\section{Tables}

Table 1 Qualitative and semi-quantitative list of minerals and compounds detected on the ornament "S116 " surface

\begin{tabular}{|c|c|c|c|c|c|c|c|}
\hline & Fragment & Point 1 & Point 2 & Point 3 & Point 4 & Point 5 & Point 6 \\
\hline $\begin{array}{l}\text { Appearance } \\
\text { Composition }\end{array}$ & $\begin{array}{l}\text { Orange } \\
\text { surface }\end{array}$ & $\begin{array}{l}\text { Orange } \\
\text { surface } \\
\text { with } \\
\text { dust }\end{array}$ & $\begin{array}{l}\text { Orange } \\
\text { surface }\end{array}$ & $\begin{array}{l}\text { Weathered } \\
\text { white } \\
\text { substrate }\end{array}$ & $\begin{array}{l}\text { Orange } \\
\text { surface }\end{array}$ & $\begin{array}{l}\text { Weathered } \\
\text { white } \\
\text { substrate }\end{array}$ & $\begin{array}{l}\text { Orange } \\
\text { surface }\end{array}$ \\
\hline $\begin{array}{l}\text { Calcite } \\
\left(\mathrm{CaCO}_{3}\right)\end{array}$ & $81 \%$ & $40 \%$ & $74 \%$ & $70 \%$ & $73 \%$ & $72 \%$ & $68 \%$ \\
\hline $\begin{array}{l}\text { Gypsum } \\
\left(\mathrm{CaSO}_{4} \cdot 2 \mathrm{H}_{2} \mathrm{O}\right)\end{array}$ & $7 \%$ & $20 \%$ & $8 \%$ & - & $19 \%$ & - & $9 \%$ \\
\hline Quartz $\left(\mathrm{SiO}_{2}\right)$ & $2 \%$ & $4 \%$ & $5 \%$ & $7 \%$ & $3 \%$ & $7 \%$ & $6 \%$ \\
\hline $\begin{array}{l}\text { Hematite } \\
\left(\mathrm{Fe}_{2} \mathrm{O}_{3}\right)\end{array}$ & $1 \%$ & $5 \%$ & $2 \%$ & $2 \%$ & $3 \%$ & - & $14 \%$ \\
\hline Halite (NaCl) & $1 \%$ & $5 \%$ & $4 \%$ & $21 \%$ & $2 \%$ & $21 \%$ & $3 \%$ \\
\hline Ettringite & $8 \%$ & - & $7 \%$ & - & - & - & - \\
\hline $\begin{array}{l}\text { Feldspar } \\
\left(\mathrm{KAISi}_{3} \mathrm{O}_{8}\right)\end{array}$ & - & $26 \%$ & - & - & - & - & - \\
\hline
\end{tabular}


Table 2 Qualitative and semi-quantitative list of minerals and compounds detected on the balustrade

\begin{tabular}{|c|c|c|c|c|c|c|}
\hline & Point 1 & Point 2 & Point 3 & Point 4 & Point 5 & Point 6 \\
\hline $\begin{array}{l}\text { Appearance } \\
\text { Composition }\end{array}$ & $\begin{array}{l}\text { Orange } \\
\text { surface }\end{array}$ & $\begin{array}{l}\text { White } \\
\text { substrate }\end{array}$ & $\begin{array}{l}\text { Orange } \\
\text { surface }\end{array}$ & $\begin{array}{l}\text { Orange } \\
\text { surface }\end{array}$ & $\begin{array}{l}\text { Orange surface } \\
\text { loose texture }\end{array}$ & $\begin{array}{l}\text { White } \\
\text { substrate }\end{array}$ \\
\hline Calcite $\left(\mathrm{CaCO}_{3}\right)$ & $54 \%$ & $80 \%$ & $15 \%$ & $38 \%$ & $85 \%$ & $100 \%$ \\
\hline $\begin{array}{l}\text { Gypsum } \\
\left(\mathrm{CaSO}_{4} \cdot 2 \mathrm{H}_{2} \mathrm{O}\right)\end{array}$ & $18 \%$ & $9 \%$ & $39 \%$ & $19 \%$ & $3 \%$ & - \\
\hline $\begin{array}{l}\text { Weddellite } \\
\left(\mathrm{CaC}_{2} \mathrm{O}_{4} \cdot 2 \mathrm{H}_{2} \mathrm{O}\right)\end{array}$ & $17 \%$ & $10 \%$ & $31 \%$ & $37 \%$ & $7 \%$ & - \\
\hline $\begin{array}{l}\text { Whewellite } \\
\left(\mathrm{CaC}_{2} \mathrm{O}_{4} \cdot \mathrm{H}_{2} \mathrm{O}\right)\end{array}$ & $9 \%$ & - & $12 \%$ & - & - & - \\
\hline Quartz $\left(\mathrm{SiO}_{2}\right)$ & $2 \%$ & $1 \%$ & $3 \%$ & $6 \%$ & $2 \%$ & - \\
\hline $\begin{array}{l}\text { Hematite } \\
\left(\mathrm{Fe}_{2} \mathrm{O}_{3}\right)\end{array}$ & - & - & - & - & $1 \%$ & - \\
\hline Halite $(\mathrm{NaCl})$ & - & - & - & - & $2 \%$ & - \\
\hline
\end{tabular}

Table 3 Comparison between the orange patinas on the sample "S-116" and on the Royal Cloister balustrade.

\begin{tabular}{|lll|}
\hline Composition & $\begin{array}{l}\text { S-116 } \\
\text { Gypsum and hematite, with } \\
\text { minor ettringite and } \\
\text { alluminosilicates. No calcium } \\
\text { oxalates. }\end{array}$ & $\begin{array}{l}\text { Balustrade } \\
\text { Abundant weddellite and whewellite on the } \\
\text { surface. }\end{array}$ \\
& $\begin{array}{l}\text { The orange layer has an imprint } \\
\text { of shaping, homogenous in color } \\
\text { and thickness, it shows obvious } \\
\text { lamination from the substrate. }\end{array}$ & $\begin{array}{l}\text { The orange patina is closely adherent to the } \\
\text { limestone substrate, no visible separate } \\
\text { lamination, the color is not uniform on the } \\
\text { surface. }\end{array}$ \\
$\begin{array}{l}\text { Decay } \\
\text { Pattern }\end{array}$ & $\begin{array}{l}\text { Surface layer is flaking, a higher } \\
\text { content of halite and nitratine } \\
\text { were detected from the white } \\
\text { substrate under the peeled off } \\
\text { lamination, indicating a typical } \\
\text { salt decay process. }\end{array}$ & $\begin{array}{l}\text { Patina is lost preferentially at the ridges and } \\
\text { bulges, scratches can be seen. It could be due } \\
\text { to a higher crystallization pressure of salt } \\
\text { solution at protruded parts, or the protrusion } \\
\text { endures more natural and artificial } \\
\text { mechanical attack. }\end{array}$ \\
\hline
\end{tabular}




\section{Figures}

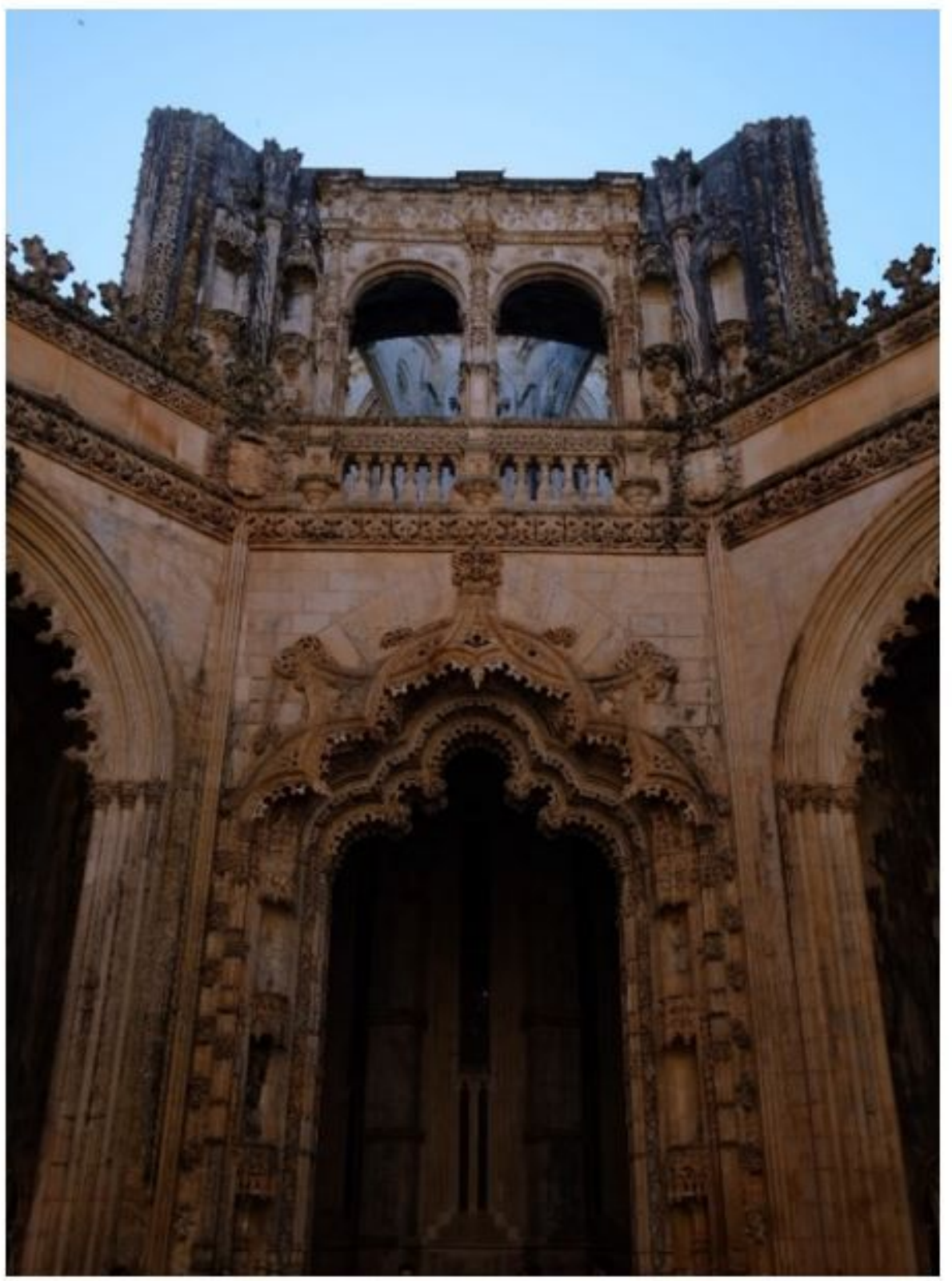

\section{Figure 1}

Facade and ornaments with orange patina at the Imperfect Chapels, Batalha Monastery 


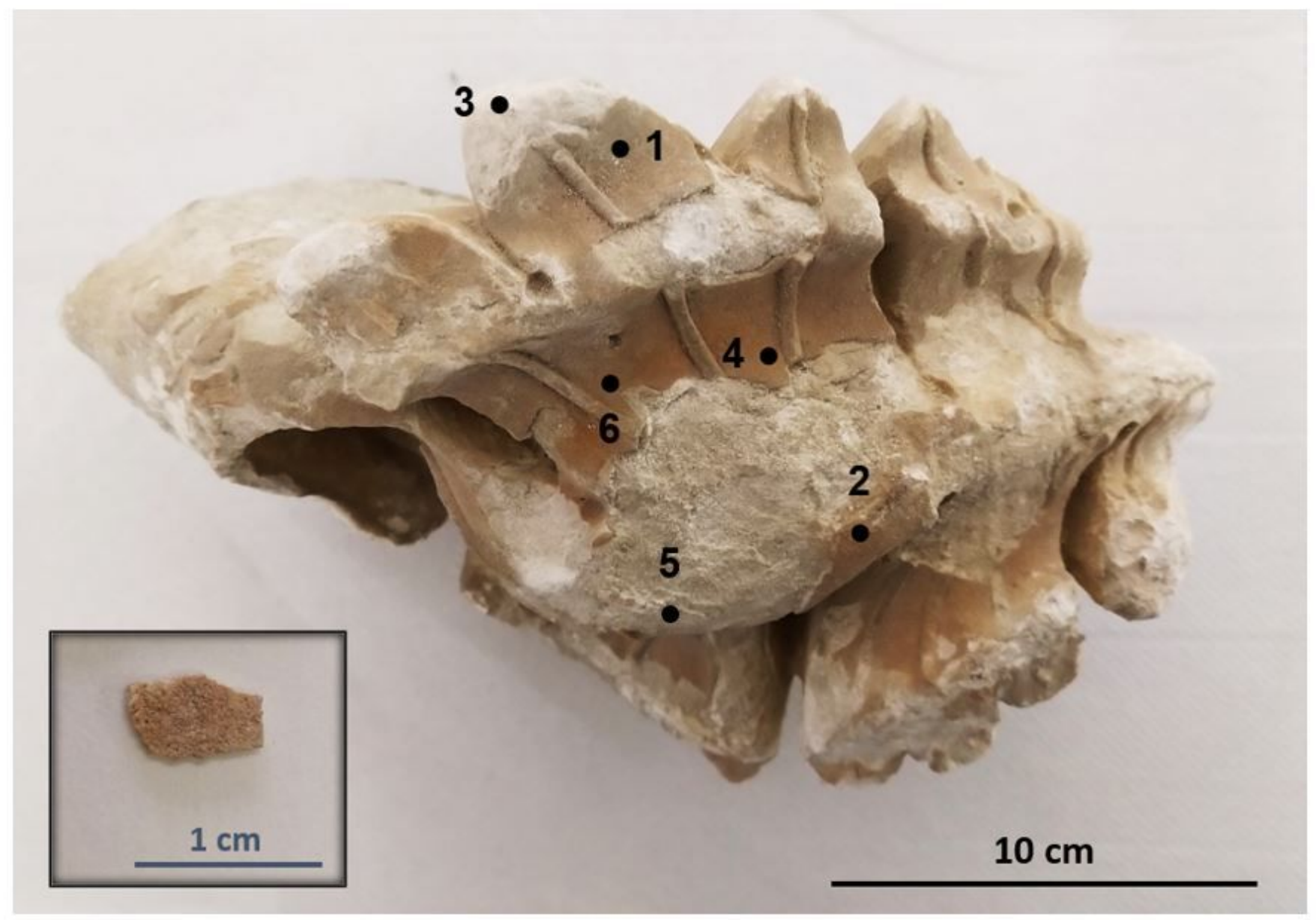

Figure 2

Ornament "S-116" and the peeled off surface fragment 


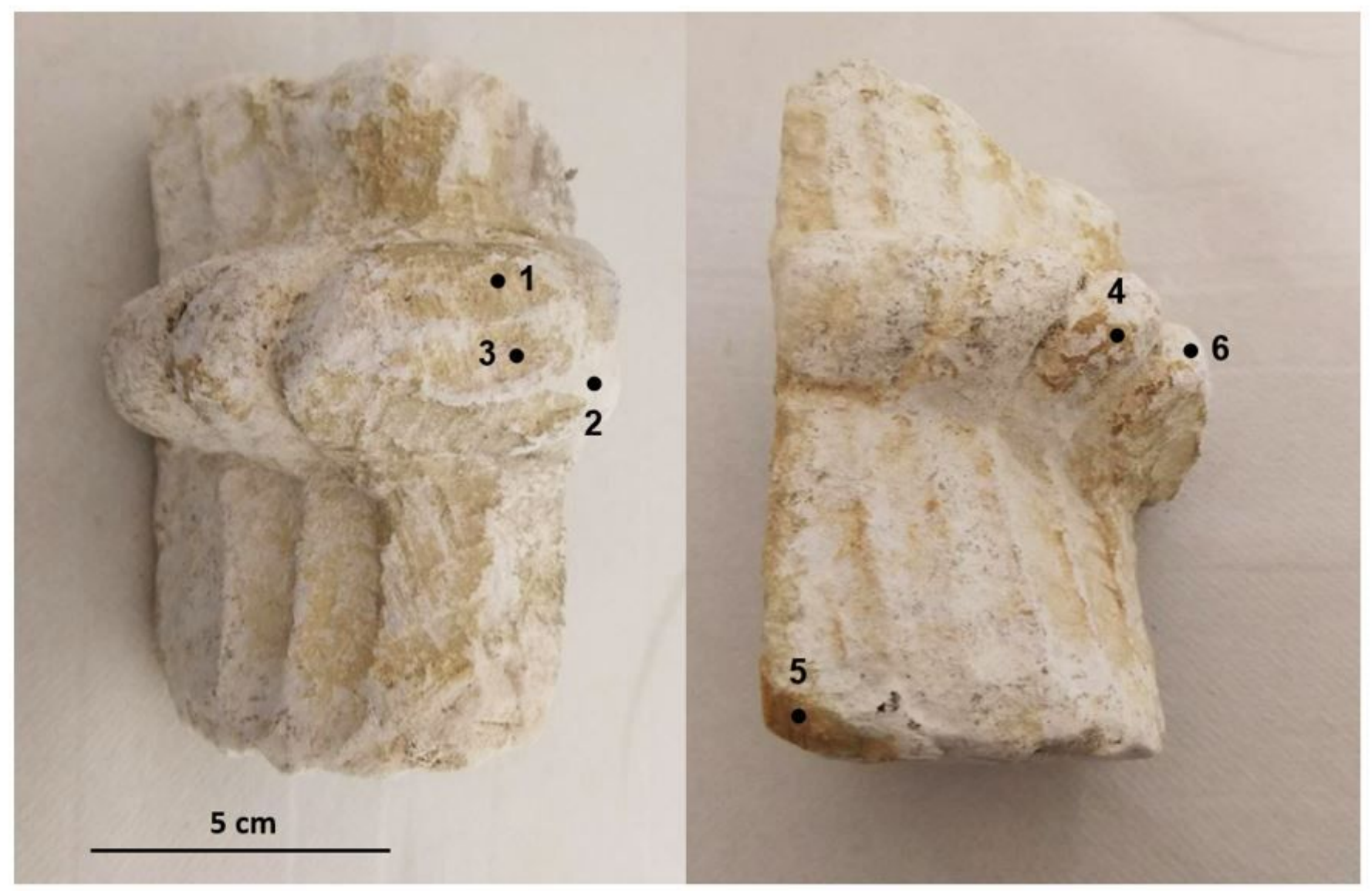

Figure 3

The sample balustrade from the Royal Cloister of the Monastery 


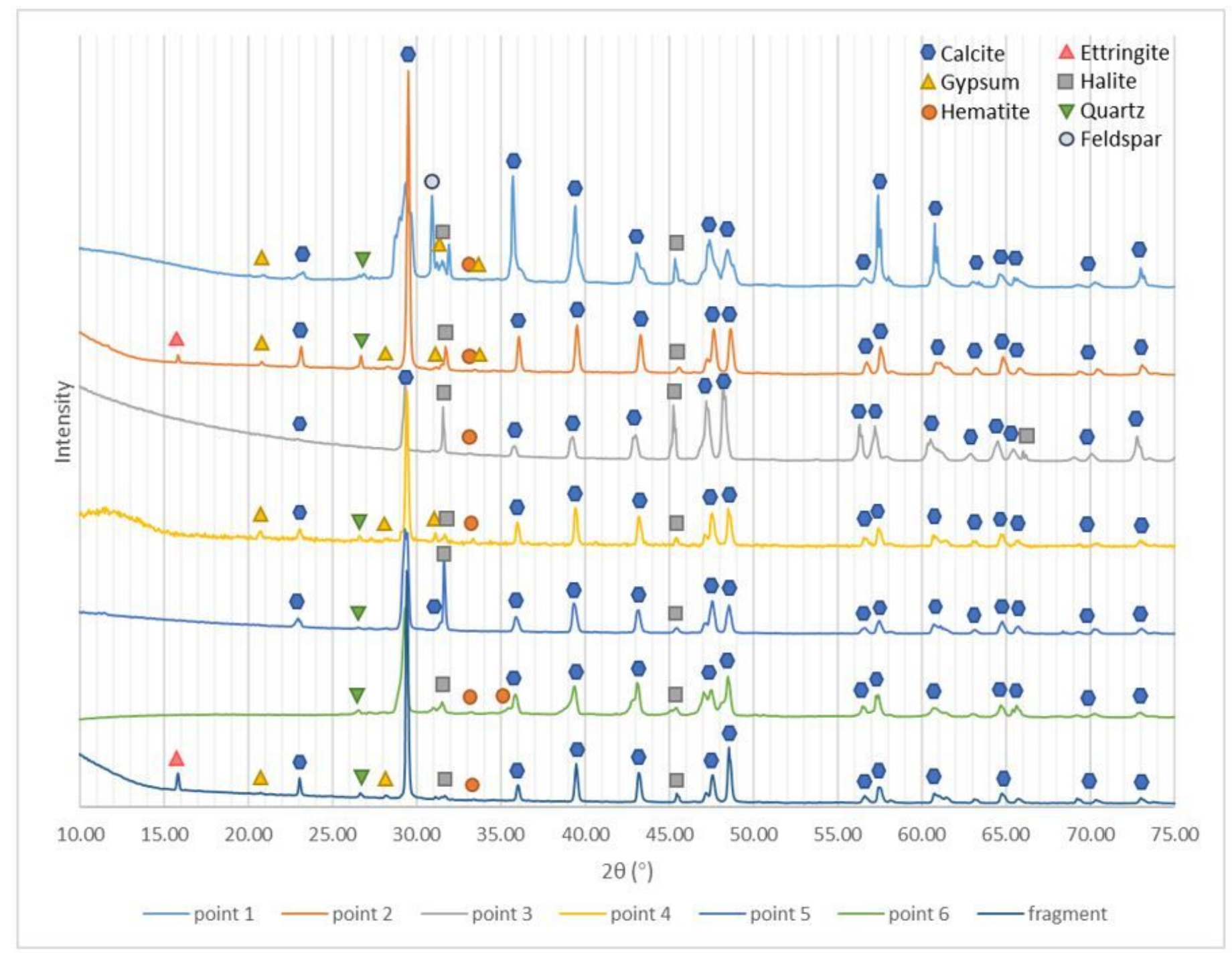

Figure 4

XRD results of multiple points on ornament "S-116" and the peeled-off fragment 

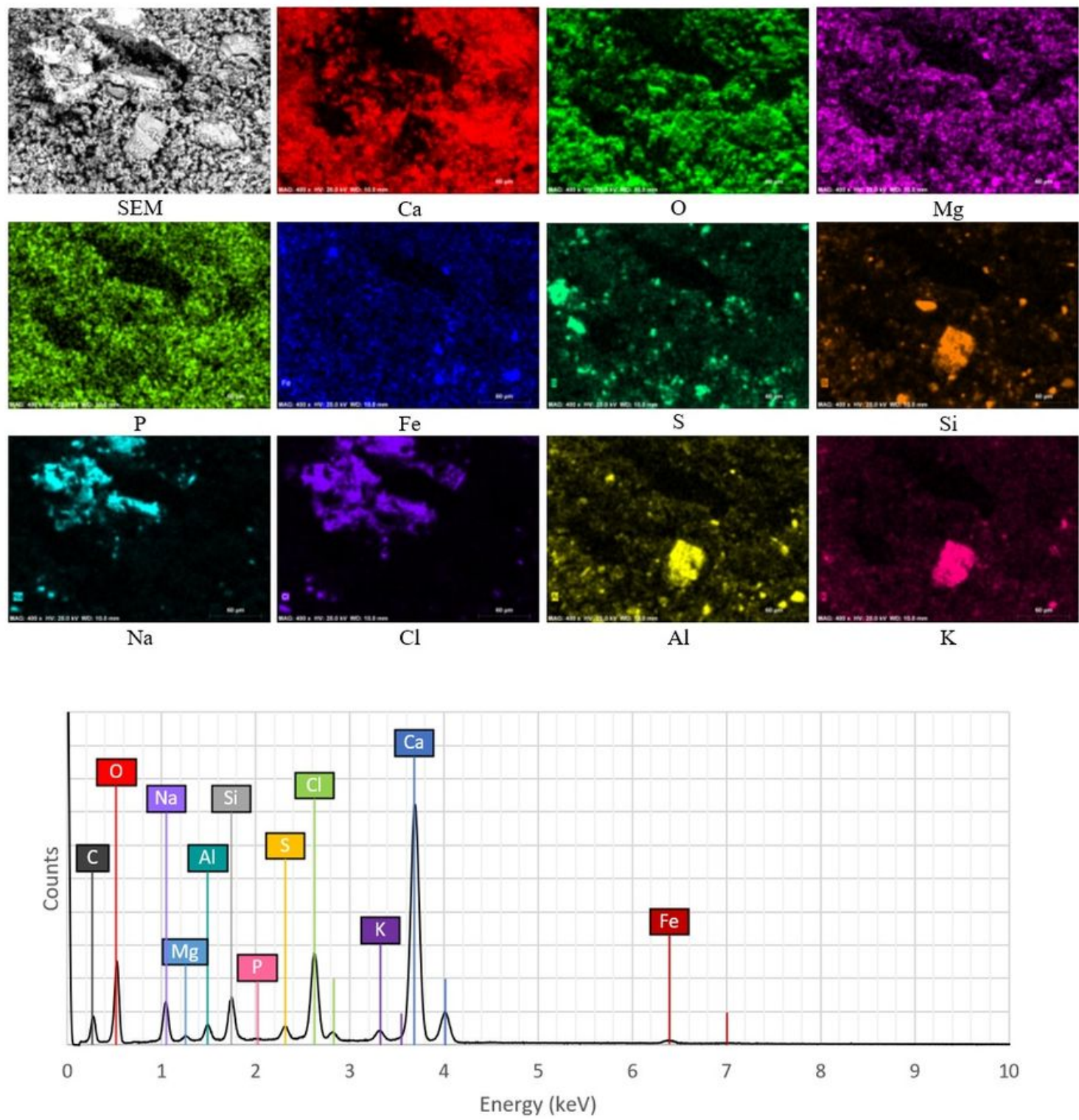

Figure 5

SEM-EDS element mapping of ornament "S-116" fragment 


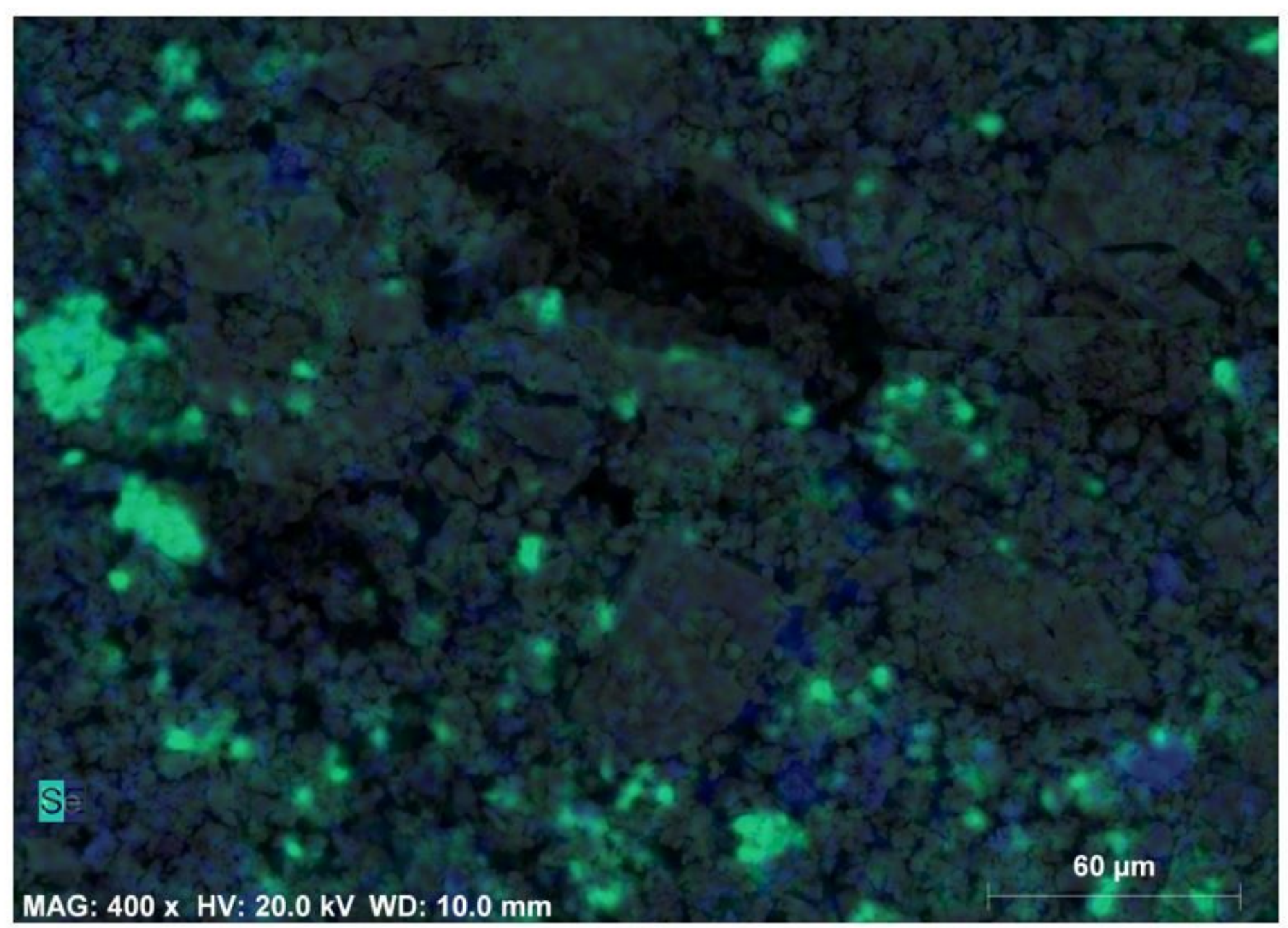

\section{Figure 6}

Overlapped element mapping of Fe (blue) and S (green) with the morphology photo 


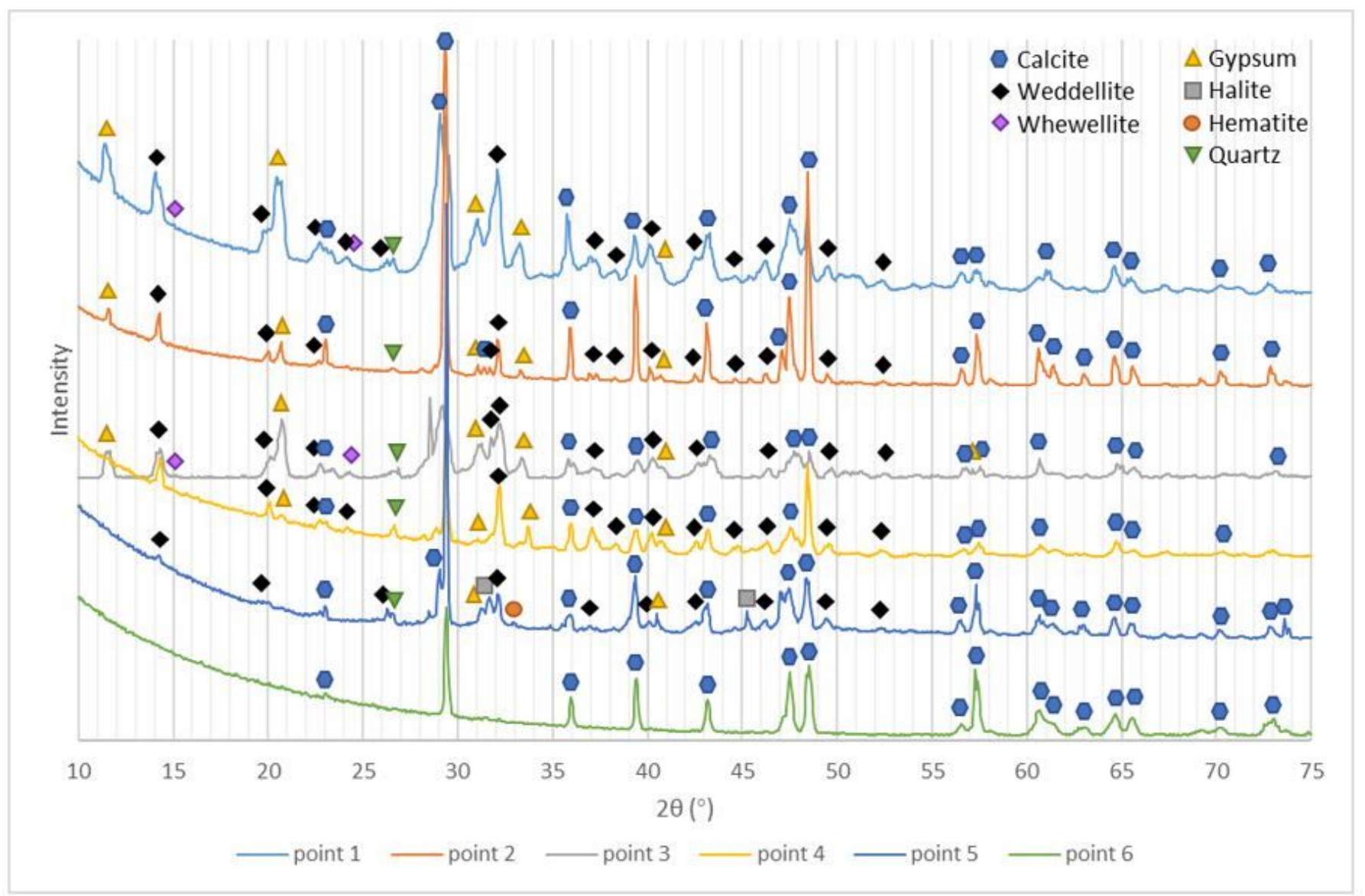

Figure 7

XRD results of multiple points on the Royal Cloister balustrade
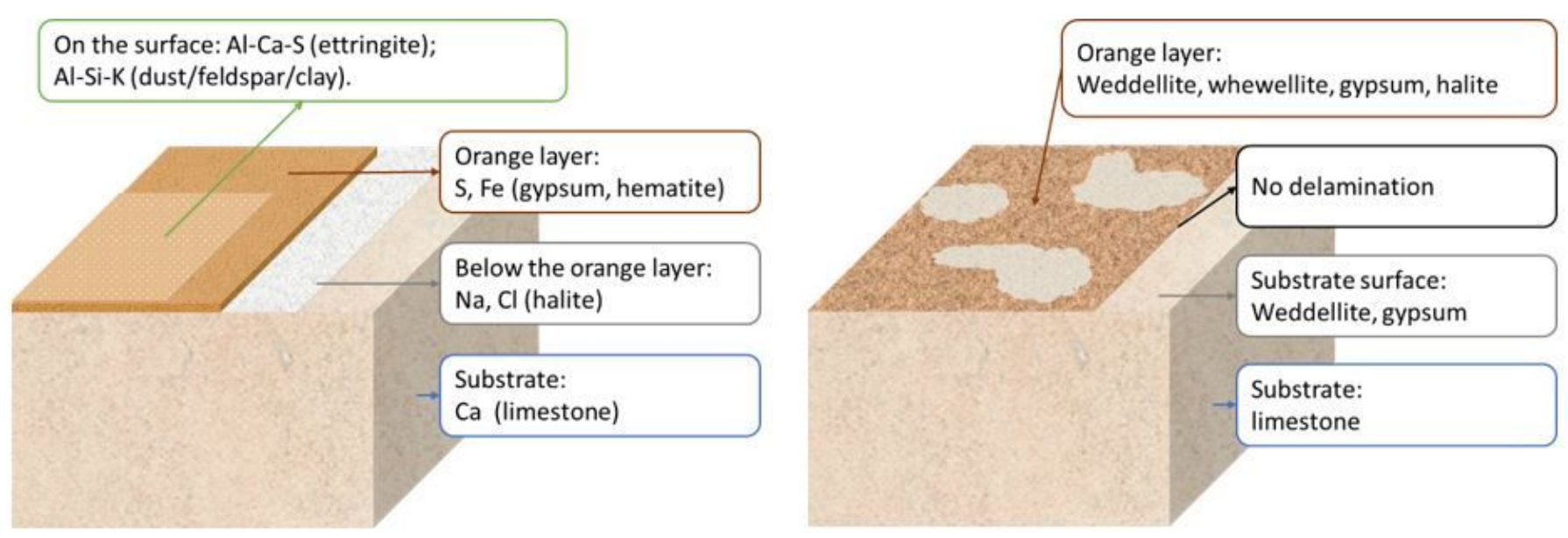

Figure 8

Sketch of the sample "S-116" (left) and the balustrade (right) 